\title{
Seasonal nutrient dynamics and biomass quality of giant reed (Arundo donax L.) and miscanthus (Miscanthus $x$ giganteus Greef et Deuter) as energy crops
}

\author{
Nicoletta Nassi o Di Nasso, Neri Roncucci, Federico Triana, Cristiano Tozzini, Enrico Bonari \\ Land Lab, Scuola Superiore S. Anna, Pisa, Italy
}

\begin{abstract}
The importance of energy crops in displacing fossil fuels within the energy sector in Europe is growing. Among energy crops, the use of perennial rhizomatous grasses (PRGs) seems promising owing to their high productivity and their nutrient recycling that occurs during senescence. In particular, nutrient requirements and biomass quality have a fundamental relevance to biomass systems efficiency. The objective of our study was to compare giant reed (Arundo donax L.) and miscanthus (Miscanthus $\times$ giganteus Greef et Deuter) in terms of nutrient requirements and cellulose, hemicellulose and lignin content. Hence, the aim was to identify, in the Mediterranean environment, the optimal harvest time that may combine, besides a high biomass yield, high nutrient use efficiency and a good biomass quality for second generation biofuel production. The research was carried out in 2009, in San Piero a Grado, Pisa (Central Italy; latitude $43^{\circ} 41^{\prime} \mathrm{N}$, longitude $10^{\circ} 21$ ' E), on seven-year-old crops in a loam soil characterised by good water availability. Maximum above-ground nutrients content were generally found in summer. Subsequently, a decrease was recorded; this suggested a nutrient remobilisation from above-ground biomass to rhizomes. In addition, miscanthus showed the highest $\mathrm{N}$, P, and $\mathrm{K}$
\end{abstract}

Correspondence: Nicoletta Nassi o Di Nasso, Land Lab, Scuola Superiore Sant'Anna di Pisa via Santa Cecilia 3, 56127, Pisa, Italy.

E-mail: n.nassiodinasso@sssup.it

Key words: giant reed, miscanthus, PRGs, nutrient concentration, nutrient content, nutrient use efficiency, second generation biofuel.

Acknowledgements: the authors wish to thank Dr. Fabio Taccini from Centro di Ricerche Interuniversitario Biomasse da Energia (CRIBE) for his suggestions during the field trial setup and data collection. In addition, we would like to acknowledge Mr. Alessandro Pannocchia, Mr. Giovanni Melai and Mr. Marco Della Croce from the "Enrico Avanzi" Interdepartmental AgroEcological Research Centre (CIRAA) of the University of Pisa for their technical support. A special thanks goes to Dr. Giorgio Ragaglini for helpful comments on this paper. We also thank the anonymous reviewer and the editor for discussions and many constructive comments.

Received for publication: 8 October 2010.

Accepted for publication: 12 May 2011.

(C) Copyright N. Nassi o Di Nasso et al., 2011

Licensee PAGEPress, Italy

Italian Journal of Agronomy 2011; 6:e24

doi:10.4081/ija.2011.e24

This work is licensed under a Creative Commons Attribution NonCommercial 3.0 License (CC BY-NC 3.0). use efficiency, probably related to its higher yield and its $\mathrm{C} 4$ pathway. Regarding biomass quality, stable values of cellulose (38\%), hemicellulose (25\%) and lignin (8\%) were reported from July onwards in both crops. Hence, these components appear not to be discriminative parameters in the choice of the harvest time in the Mediterranean environment. In conclusion, our results highlighted that, in our environment, a broad harvest period (from late autumn to winter) seems suitable for these PRGs. However, further research is required to evaluate the role of rhizomes in nutrient storage and supply during the growing season, as well as ecological and productive performances in marginal lands, in particular where water availability may be a limiting factor.

\section{Introduction}

The increasing petroleum price and negative impact of fossil fuels on the environment are encouraging the use of lignocellulosic materials to help meet energy needs (Lemus et al., 2009; Amougou et al., 2010). Among energy crops, the use of perennial rhizomatous grasses (PRGs), such as miscanthus (Miscanthus $\times$ giganteus Greef et Deuter) and giant reed (Arundo donax L.), seems promising owing to their high productivity and to the nutrient recycling that occurs during growth and senescence (Angelini et al., 2009; Heaton et al. 2009; Zub et al., 2009; Smith and Slater, 2010). In addition, these lignocellulosic crops are thought to have positive effects on soil properties, biodiversity, energy balance, greenhouse gas mitigation and carbon footprint, especially when their cultivation is compared with arable crops (Rowe et al., 2009). Although several studies have been conducted on mineral fertilisation responses of these two crops (Angelini et al, 2005; Cosentino et al., 2007b; Smith and Slater, 2010; Cadoux et al., 2011), little information is available about differences in nutrient dynamics of miscanthus and giant reed. Smith and Slater (2011) have demonstrated that, in mature miscanthus crops, harvest time critically influences nitrogen dynamics. Moreover, a delayed harvest can reduce nitrogen concentration in biomass feedstock, dropping nitrogen fertiliser requirements (Heaton et al., 2009). Nonetheless, biomass losses should also be taken into account in delayed harvests. In the literature, it is found that the highest nutrient content occurs in late summer. Thereafter, nutrients are effectively translocated to rhizomes and then remobilised during shoot elongation the following year (Beale and Long, 1997; Himken et al., 1997; Smith and Slater, 2011). Moreover, Himken et al. (1997) and Beale and Long (1997) highlighted that miscanthus low input requirements could be associated with its C4 pathway. On the other hand, little is known about giant reed nutrient dynamics under European conditions. Most of the researchers have concentrated on natural plant communities dominated by giant reed (Sharma et al., 1999). In the Mediterranean environment, preliminary studies were conducted in Central Italy, generally observing low 
nutrient requirements (Nassi o Di Nasso et al., 2009a).

Lignocellulosic biomass from miscanthus and giant reed can produce heat, electricity or transportation fuels using several conversion technologies. Currently, biomass-based transportation fuels are identified as first and second generation biofuels (Sassne et al., 2008). In particular, second generation biofuels can be produced from a variety of lignocellulosic feedstocks (Cherubini and Jungmeier, 2010), such as crop residues and energy crops. Cellulose, hemicellulose and lignin are the three major components of lignocellulosic raw materials; these are closely associated in a complex crystalline structure. Following some processing steps (pretreatment, hydrolysis and fermentation), cellulose and hemicellulose are transformed into bioethanol, while lignin remains largely unconverted. Lignin, though, can be reused within the bioethanol production system as an energy source or can be used for synthesising high-value chemicals (Keshwani and Cheng, 2009). For this reason, the study of lignocellulosic component dynamics and their variation among different species is important in improving knowledge on overall bioenergy chain performances.

Our study used an experimental framework of miscanthus $(M . \times$ giganteus) and giant reed (A. donax) field trials carried out in Pisa (Central Italy). The following research questions were addressed:

1. Does the N, P and K concentration in the above-ground biomass differ between miscanthus and giant reed during the growing season?

2. How much N, P and K are removed by miscanthus and giant reed crops harvested at different times?

3. How much does biomass quality (referring to cellulose, hemicellulose and lignin percentage) differ between miscanthus and giant reed during the cropping cycle?

Gathered knowledge could be useful in identifying, in the Mediterranean area, optimal harvest times that may combine elevated biomass yield, high nutrient use efficiency and good biomass quality for second generation biofuel production.

\section{Materials and Methods}

A field trial was established in 2003 at the Enrico Avanzi Interdepartmental Centre for Agro-Environmental Research (CIRAA) of the University of Pisa, comparing miscanthus $(M . \times$ giganteus $)$ and giant reed (A. donax). The soil was a typical Xerofluvent, representative of the lower Arno river plain (sand $41 \%$, silt $38.5 \%$, clay $20.5 \%$, organic matter $2 \%$, total nitrogen $1.1 \mathrm{~g} / \mathrm{kg}$, assimilable phosphorus $6.2 \mathrm{mg} / \mathrm{kg}$, exchangeable potassium $138.8 \mathrm{mg} / \mathrm{kg}$ ), characterised by a shallow water table. The experimental design was a randomised block with three replications (plots $7 \mathrm{~m} \times 7 \mathrm{~m}$ each). Tillage was conducted in autumn of 2002 after wheat harvesting, and consisted of medium-depth ploughing $(30-40 \mathrm{~cm})$. Seedbed preparation was conducted in spring, immediately before planting. For both crops, establishment was performed using rhizomes of about $500 \mathrm{~g}$, with at least a couple of buds. Rhizomes were planted at $10-20 \mathrm{~cm}$ of soil depth, at $0.50 \times 1 \mathrm{~m}$ spacing (20,000 plants/ha). Taking soil nutrient availability into account and following fertiliser doses reported by Beale and Long (1997), fertilisers were distributed at a rate of $100 \mathrm{~kg} \mathrm{~N} / \mathrm{ha}$ (urea), $100 \mathrm{~kg} \mathrm{P}_{2} \mathrm{O}_{5} / \mathrm{ha}$ (triple superphosphate) and $100 \mathrm{~kg} \mathrm{~K} \mathrm{O} / \mathrm{ha}$ (potassium sulphate). Nitrogen fertiliser was broadcasted in the establishment year: $50 \%$ as preplant and $50 \%$ as side dressing when plants were $0.30-0.40 \mathrm{~m}$ tall. In the following years, $\mathrm{P}_{2} \mathrm{O}_{5}$ and $\mathrm{K}_{2} \mathrm{O}$ fertilisers were applied during winter, while $\mathrm{N}$ was applied entirely in spring at the beginning of the growing season. Plots were kept weed-free by hoeing. No crop diseases were detected during the experimental period and irrigation treatment was never necessary.

The experiment began when the crop stands were seven years old, an age when they are generally considered mature (Christian et al.,
2008; Angelini et al., 2009). Total above-ground biomass was measured at ten dates spread across the annual crop production cycle during 2009. At each sampling date, an area of $1 \mathrm{~m}^{2}$ from each plot was collected and fresh-weighed. Subsamples were dried to constant mass at $60^{\circ} \mathrm{C}$. Hence, crop dry matter percentage was calculated. Afterwards, each dried sample was milled to powder in a Retsch SM1 rotor mill (particle size $<297 \mathrm{~mm}$ ) for subsequent chemical analysis. Nitrogen concentration was determined by the Kjeldahl method, while $\mathrm{P}$ and $\mathrm{K}$ concentrations were determined by spectrophotometric analysis and flame photometry, respectively. Nutrient content was calculated as the product of nutrient concentration and dry yield. Nutrient use efficiency (NUE) was expressed as the ratio between dry matter production and nutrient content (g/g), according to Beale and Long (1997). Therefore, NUE indicates the total biomass produced per unit of nutrient absorbed (Cosentino et al., 2007a). From July to January, cellulose, hemicellulose and lignin contents of miscanthus and giant reed were determined using the Van Soest method (1991). Data were analysed by one-way ANOVA in order to evaluate differences, at each sampling date, between the two species during the growing season. A post-hoc test was performed to compare results from each sampling date, using the LSD test $(\alpha=0.05)$. An arcsine transformation was applied to all data expressed as a percentage before performing ANOVA (Gomez and Gomez, 1984).

\section{Results and Discussion}

Seasonal monthly mean air temperature and rainfall are shown in Figure 1. Air temperature increased from March to August with maximum values $\left(>30^{\circ} \mathrm{C}\right)$ in July and August. Although the total amount of rainfall was similar to the long-term average (933 vs $902 \mathrm{~mm}$, respectively), its distribution was quite different. Compared to the long term, higher rainfall was recorded during 2009 in early spring, September and winter $(+60 \%)$. On the other hand, a very dry period was recorded during late spring and summer (Figure 1).

Figure 2A reports the above-ground biomass accumulation of giant reed and miscanthus. After the end of June, differences between the two species became significant. Miscanthus maximum above-ground dry yield was attained at the end of August (39 t/ha) and declined progressively to 28 tha (-30\%), as a consequence of leaf loss (data not shown). Giant reed maximum above-ground dry yield was achieved at the end of September, with a value of $32 \mathrm{t} / \mathrm{ha}$, which remained stable until February. Dry matter percentage increased almost linearly over the course of the experiment (Figure 2B). Maximum values (about 60\%) were achieved in February, when no significant differences

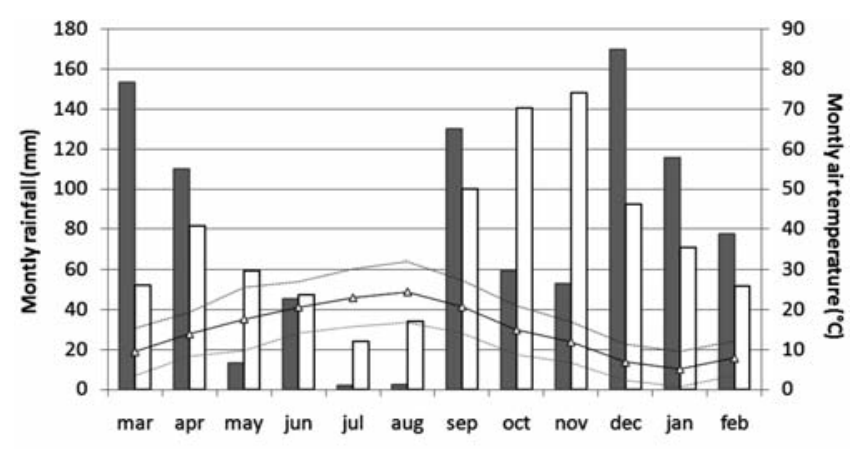

$\square$ Rainfall (2009-2010) $\square$ Long term rainfall (1986-2008) — Tmax — Tmin - - Tmean

Figure 1. Meteorological data during the 2009 growing season in comparison with the long-term average (1986-2008) at the field experimental site (Pisa, Italy, 4340' N, $10^{\circ} 19^{\prime} \mathrm{E}$ ). 
between the two species were recorded. A high dry matter percentage of the lignocellulosic material is considered advantageous in terms of reduced costs in drying plant material prior to combustion (Himken et al., 1997) and bioethanol production (Öhgren et al., 2006).

Macronutrient (N, P and $\mathrm{K}$ ) concentration dynamics showed the same pattern in both species, with progressively decreasing values during the growing season (Figure 3A-C). This confirmed previous findings reported by several authors, for either miscanthus or giant reed cultivated under different management and environmental conditions (Beale and Long, 1997; Himken et al., 1997; Sharma et al., 1999; Christian et al., 2008; Heaton et al., 2009; Nassi o Di Nasso et al., 2009a). Indeed, nutrient concentrations in the above-ground material appear to become diluted as the above-ground dry matter increased, and then declined further as the canopy senesced (Beale and Long, 1997). In fact, throughout the growing season, nutrient concentration decline was most pronounced in the period of active growth (JuneAugust), while from late summer to winter the change was negligible. Purely in terms of N, P and K concentrations, little benefits would thus be obtained by harvesting either in autumn or in winter. In general, nitrogen concentration declined steadily from a high of $>1 \%$ in young shoot tissue in spring to $<0.5 \%$ in late autumn, confirming results reported by Heaton et al. (2009). Significantly higher values of $\mathrm{N}$ were recorded in miscanthus from May to July. From summer onwards, no difference was found between crops. The overall $\mathrm{N}$ reduction throughout the growing season was $-77 \%$ and $-88 \%$ for giant reed and miscanthus, respectively (Figure 3A). Our miscanthus values were in agreement with those of Beale and Long (1997), Kahle et al. (2001) and Heaton et al. (2009), while they were lower than those reported by Himken et al. (1997). Phosphorus concentration was much lower than that for $\mathrm{N}$ and $\mathrm{K}$. Giant reed and miscanthus showed significantly dif-
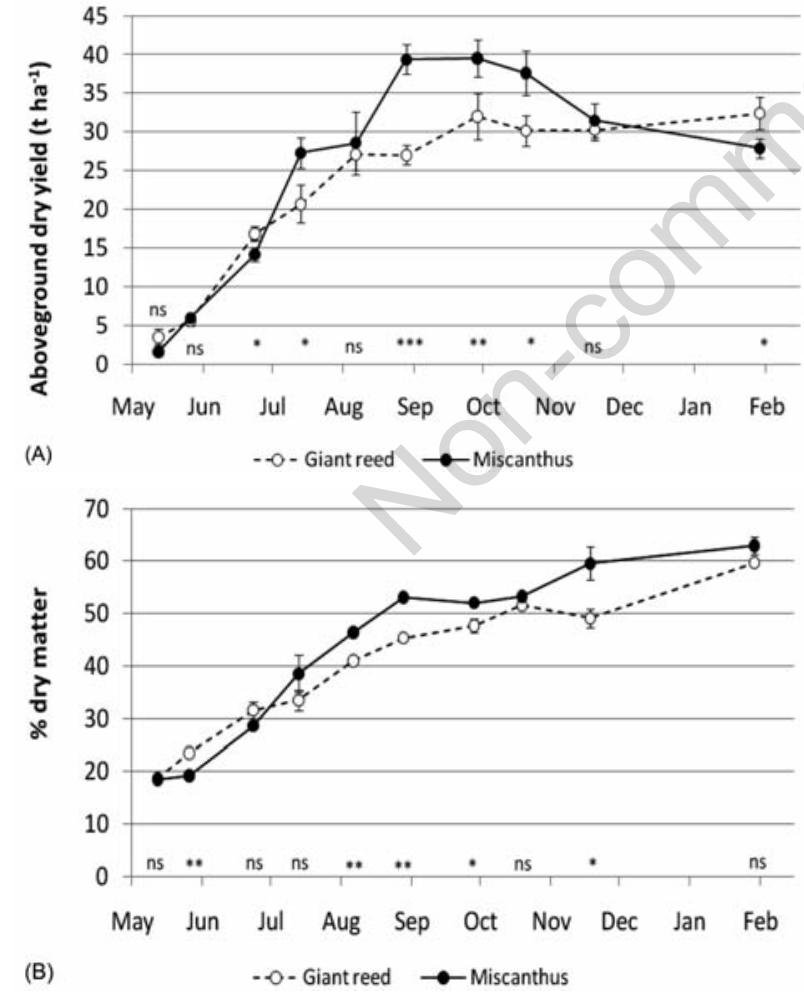

Figure 2. Seasonal variation (2009) in above-ground biomass accumulation $(A)$ and dry matter percentage $(B)$ of giant reed and miscanthus in Pisa, Italy $\left(43^{\circ} 40^{\prime} \mathrm{N}, \mathbf{1 0}^{\circ} 19^{\prime} \mathrm{E}\right) . \circ$, giant reed; •, miscanthus; bars represent the standard deviation; ${ }^{*}, * *,{ }^{* *}$, significant differences at $\mathbf{P}<0.05, P<0.01, P<0.001$, respectively; ns, no significant differences. ferent values in early May and from July to September. Afterwards, crops did not differ in P, both ranging from $0.12 \%$ to $0.08 \%$ (Figure $3 \mathrm{~B}$ ). Potassium concentration was the highest among the three macronutrients. Potassium was the only mineral element that showed significantly different values between giant reed and miscant hus during the whole season, except for June and July (Figure 3C). In young shoots, K declined from $3.4 \%$ to $0.7 \%$ in giant reed and from $2.8 \%$ to $0.5 \%$ in miscanthus. For both species, $\mathrm{P}$ and $\mathrm{K}$ results confirmed those reported by some authors for miscanthus (Beal and Long, 1997; Himken et al., 1997; Kahle et al., 2001) and giant reed (Sharma et al., 1999; Nassi o Di Nasso et al., 2009a). In addition, when these two PRGs are compared with annual graminaceous crops (i.e. maize and wheat), a lower nutrient concentration is revealed (Beale and Long, 1997).

The above-ground nutrient content is defined as the product of dry matter and nutrient concentration. Results showed that P content was characterised by the lowest values, while $\mathrm{K}$ content was the highest (Figure 4). Overall, N, P and K contents presented a similar dynamic in both species. They reached maximum values in late July to early August and then they decreased until winter, confirming trends reported by Beale and Long (1997) and Heaton et al. (2009). Only P content in miscanthus obtained its maximum in October. The rapid increase in nutrient content of shoots between May and July suggests that giant reed and miscanthus are highly efficient in nutrient acquisition. A possible explanation could be related to their deep rooting system (Monti and
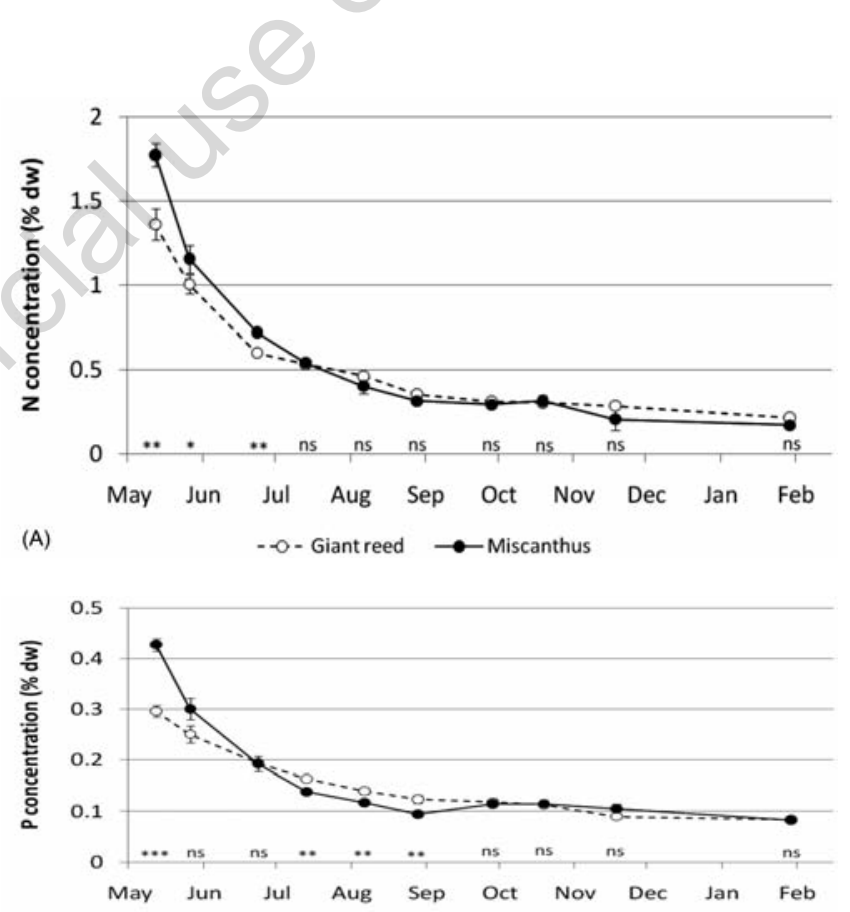

(B)

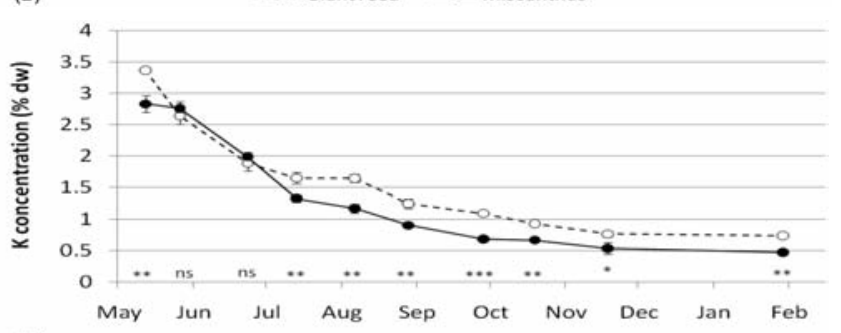

(C)

$$
-\infty \text { - Giant reed } \longrightarrow \text { Miscanthus }
$$

Figure 3. Seasonal variation (2009) in N (A), P (B) and $K(C)$ concentrations of giant reed and miscanthus in Pisa, Italy $\left(43^{\circ} 40^{\prime} \mathrm{N}\right.$, $\left.10^{\circ} 19^{\prime} \mathrm{E}\right) . \circ$, giant reed; $\bullet$, miscanthus; bars represent the standard deviation; *, $* *, * * *$, significant differences at $\mathbf{P}<0.05$, $\mathbf{P}<0.01, P<0.001$, respectively; ns, no significant differences. 
Zatta, 2009), which remains dormant during winter but can respond quickly to a rapid increase in the plant's demand for nutrients at the start of growth in spring (Himken et al., 1997). Some authors have underlined that macronutrient content decline is consistent with nutrient cycling in perennial rhizomatous grasses and it represents a survival strategy for those species (Himken et al., 1997; Sharma et al., 1999; Heaton et al., 2009; Nassi o Di Nasso et al., 2009a). Furthermore, macronutrient translocation towards the rhizome may represent an environmental friendly strategy that could reduce fertiliser application (Rowe et al., 2009). Concerning N content, significant differences were recorded between the species, although no clear pattern could be identified. Nevertheless, miscanthus $\mathrm{N}$ content was significantly higher than that of giant reed in late autumn, while it was significantly lower in winter. Maximum above-ground content was reached in summer, with about 130 $\mathrm{kg} / \mathrm{ha}$ in both crops, while in November values decreased to 86 and 64 $\mathrm{kg} / \mathrm{ha}$ in giant reed and miscanthus, respectively. At the end of the growing season (February), $N$ content dropped further to 69 and $53 \mathrm{~kg} / \mathrm{ha}$ (Figure 4A). This agrees with the results of Heaton et al. (2009) for miscanthus. For giant reed, Nassi o Di Nasso et al. (2009a) reported lower values during the whole growing season, probably owing to the crop age (15 years old) and to lower yields (about 20 t/ha). Phosphorus aboveground content did not differ significantly between both species. Maximum P content was about $38 \mathrm{~kg} / \mathrm{ha}$ and $45 \mathrm{~kg} / \mathrm{ha}$ in giant reed and miscanthus, respectively. Afterwards, it decreased to about $25 \mathrm{~kg} / \mathrm{ha}$ in both crops at the end of January (Figure 4B). In miscanthus, lower values were reported by Beale and Long (1997) and Himken et al. (1997) consistent with their lower dry yields. Significant differences were recorded between species in $\mathrm{K}$ content. In summer, $\mathrm{K}$ content reached its maximum value (440 and $360 \mathrm{~kg} / \mathrm{ha}$ in giant reed and miscanthus, respectively) (Figure $4 \mathrm{C}$ ). The decrement rate, until late November, was nearly the same in both crops (-30\%), reaching values of about $280 \mathrm{~kg} / \mathrm{ha}$. Subsequently, K content maintained stable values, confirming results reported by Beale and Long (1997) for miscanthus crops. On the other hand, Himken et al. (1997) showed lower values in four-year-old miscanthus, probably owing to diverse environmental conditions and fertilisation level. Regarding giant reed, our values were higher than those observed by Nassi o Di Nasso et al. (2009a) with no fertilisation and dry yield of about 20 tha; hence, this information suggests a strong influence of crop yield and crop management on macronutrient content.

Finally, nutrient use efficiencies (NUEs) were taken into account in order to evaluate suitable harvest times that may combine high yields and low nutrient contents. For all three macronutrients and for both crops, NUEs increased progressively from October to January. Nitrogen NUE $\left(\mathrm{N}_{\mathrm{NUE}}\right)$ achieved minimum values of 330 and $316 \mathrm{~g} / \mathrm{g}$ in October and maximum values of 467 and $522 \mathrm{~g} / \mathrm{g}$ in late January, for giant reed and miscanthus, respectively. Average $\mathrm{N}_{\mathrm{NUE}}$ was significantly higher for miscanthus (442 vs $382 \mathrm{~g} / \mathrm{g}$ ). As suggested by Long (1983), this may be a result of the photosynthetic pathway of $\mathrm{C} 4$ crops (miscanthus) that is more efficient in its use of $\mathrm{N}$ than the $\mathrm{C} 3$ pathway (giant reed). However, a high $\mathrm{N}_{\mathrm{UE}}$ does not necessarily mean that the whole production system is efficient; in fact, $\mathrm{N}_{\mathrm{UE}}$ does not take into account losses from the system. In particular, $\mathrm{N}$ can easily be lost as gaseous $\mathrm{NO}_{\mathrm{x}}$, by
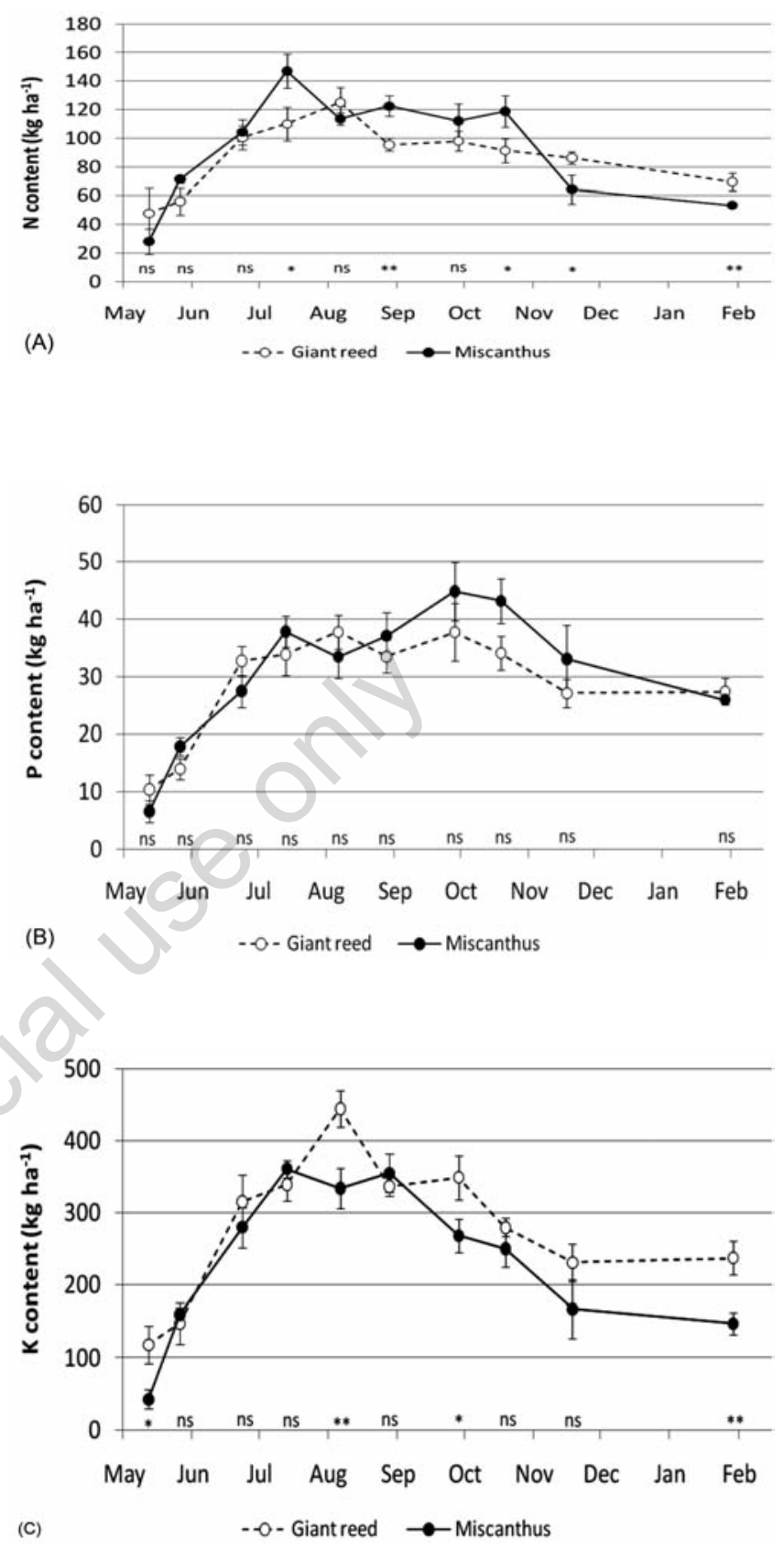

Figure 4. Seasonal variation (2009) in N (A), P (B) and $K(C)$ contents of giant reed and miscanthus in Pisa, Italy $\left(43^{\circ} 40^{\prime} \mathrm{N}\right.$, $\left.10^{\circ} 19^{\prime} \mathrm{E}\right) . \circ$, giant reed; $\bullet$, miscanthus; bars represent the standard deviation; *, **, $* * *$, significant differences at $\mathbf{P}<0.05$, $\mathbf{P}<0.01, \mathrm{P}<0.001$, respectively; ns, no significant differences.

Table 1. Nutrient use efficiencies of giant reed and miscanthus crops during 2009 growing season in Pisa (43 $40^{\prime}$ N, $\left.10^{\circ} 19^{\prime} \mathrm{E}\right)$, Italy.

\begin{tabular}{|c|c|c|c|c|c|c|}
\hline \multirow[b]{2}{*}{ Date } & \multicolumn{2}{|c|}{$\mathrm{N}_{\text {NUE }}, \mathrm{g} / \mathrm{g}$} & \multicolumn{2}{|c|}{$\mathrm{P}_{\mathrm{NUE}}, \mathrm{g} / \mathrm{g}$} & \multicolumn{2}{|c|}{$\mathrm{K}_{\mathrm{NUE}}, \mathrm{g} / \mathrm{g}$} \\
\hline & Giant reed & Miscanthus & Giant reed & Miscanthus & Giant reed & Miscanthus \\
\hline 19 October & $330 \mathrm{a}$ & $316 \mathrm{a}$ & 884 a & $870 \mathrm{a}$ & $108 \mathrm{a}$ & $150 \mathrm{a}$ \\
\hline 18 November & $351 \mathrm{~b}$ & $489 a$ & $1115 \mathrm{a}$ & $952 \mathrm{a}$ & $131 \mathrm{~b}$ & $188 \mathrm{a}$ \\
\hline 23 January & $467 \mathrm{~b}$ & $522 \mathrm{a}$ & $1183 \mathrm{a}$ & $1073 \mathrm{a}$ & $136 \mathrm{~b}$ & $189 \mathrm{a}$ \\
\hline Mean & $383 b$ & $442 a$ & $1061 a$ & $965 a$ & $125 b$ & $176 a$ \\
\hline
\end{tabular}

NUE values, followed by the same letter across species, are not significantly different $(\mathrm{P}=0.05)$. 

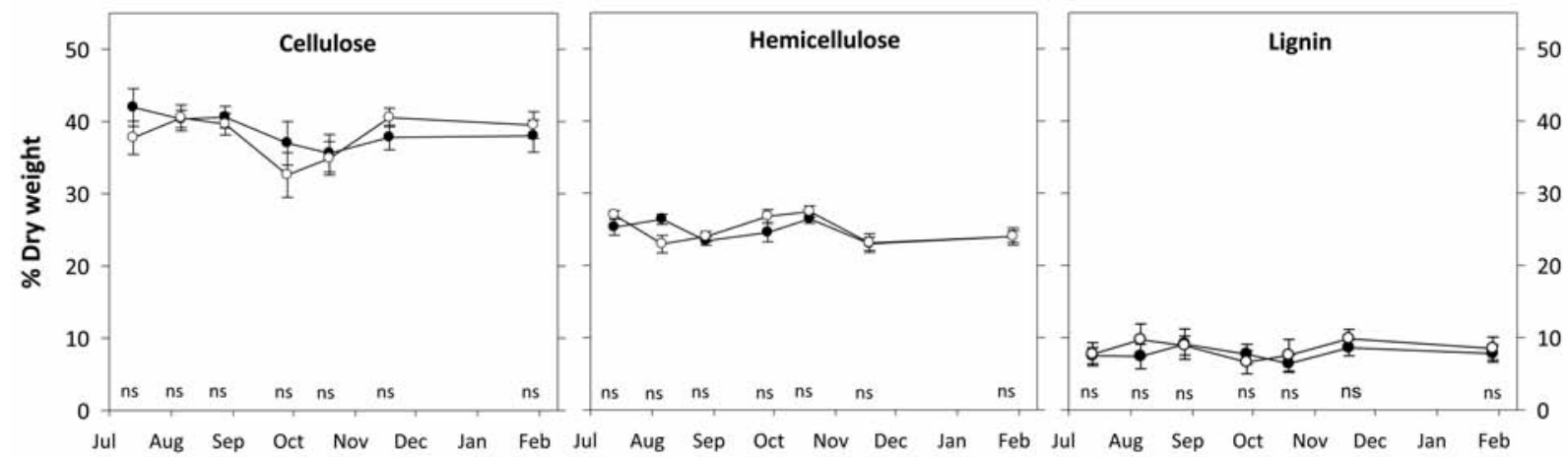

Figure 5. Seasonal variation (2009) in cellulose, hemicellulose and lignin content of giant reed and miscanthus in Pisa, Italy (43 ${ }^{\circ} 40^{\prime} \mathrm{N}$, $10^{\circ} 19^{\prime}$ E). $\circ$, giant reed; $\bullet$, miscanthus; bars represent the standard deviation; ${ }^{*},{ }^{* *},{ }^{* * *}$, significant differences at $\mathrm{P}<0.05, \mathrm{P}<0.01$, $P<0.001$, respectively; ns, no significant differences.

surface runoff or leached as nitrate (Jorgensen \& Mortensen, 1997). Mean $\mathrm{P}_{\mathrm{NUE}}$ values (October-January) were slightly higher in giant reed, showing averages of $1062 \mathrm{~g} / \mathrm{g}$, while miscanthus $\mathrm{P}_{\mathrm{NUE}}$ was around 965 $\mathrm{g} / \mathrm{g}$, with no significant differences between species. On the other hand, miscanthus showed significantly higher mean $\mathrm{P}_{\text {NUE }}$ values (176 $\mathrm{g} / \mathrm{g}$ ) compared to giant reed $(125 \mathrm{~g} / \mathrm{g})$. With regard to $\mathrm{K}_{\mathrm{NUE}}$, our results may have been affected by high soil K availability. In fact, as suggested by Cadoux et al. (2011), high soil K availability may have led to potassium luxury uptake by these two crops.

Tables 1 and 2 provide evidence that giant reed and miscanthus species show higher nutrient use efficiencies than arable crops (i.e. maize and wheat). Moreover, when compared with woody crops, PRGs confirm their high N and P NUEs. Above-ground cellulose, hemicellulose and lignin content in giant reed and miscanthus showed little variation during the growing season; average values were about $38 \%, 25 \%$ and $8 \%$, respectively. № significant differences between crops were recorded (Figure 5). For comparison, cellulose, hemicellulose, and lignin content in common agricultural residues are listed in Table 3. For switchgrass, Keshwani and Cheng (2009) have reported lower cellulose content (33\%), slightly higher hemicellulose content (26\%) and more than twice lignin content (18\%). For cellulose and hemicellulose, our giant reed results were higher than those reported by Shatalov and Pereira (2002) and Cosentino et al. (2007b), and in agreement with those of Neto et al. (1997). Regarding miscanthus, Cosentino et al. (2007b) have observed higher values of cellulose and similar values of hemicellulose. In addition, Scordia et al. (2009) reported similar cellulose content while hemicellulose and lignin contents were higher. For lignin, an increasing trend was observed from October to November in giant reed and from September to November in miscanthus (Figure 5). This behaviour should probably be linked to a progressive loss of leaves, as leaves are characterised by a lower lignin content than stems (Cosentino et al., 2007b; Nassi o Di Nasso et al., 2009b). The overall observed differences could be related to genetic variability (e.g. local ecotype used), as well as crop management and crop age, which seem to affect biomass quality (Nassi o Di Nasso et al., 2010). Moreover, the dissimilarity revealed in cellulose, hemicellulose and lignin contents could be because of the adoption of different methods for characterising the biomass. For this reason, we believe there is a need to define international methods that would facilitate comparisons among the available data (Nassi o Di Nasso et al., 2010).

\section{Conclusions}

Firstly, both species showed a decline in N, P and K concentrations throughout the season. Between the species no significant differences
Table 2. Nutrient use efficiencies of some woody and arable crops.

\begin{tabular}{lcccl} 
& N $_{\text {NUE, }} \mathrm{g} / \mathrm{g}$ & $\mathrm{P}_{\text {NUE, g }} / \mathrm{g}$ & $\mathrm{K}_{\text {NUE, }} \mathrm{g} / \mathrm{g}$ & Source \\
Poplar & $145-370$ & $1000-2000$ & $256-370$ & Jug et al., 1999 \\
Willow & $152-244$ & $909-1429$ & $323-500$ & Jug et al.., 1999 \\
\hline Eucalyptus & 219 & 3477 & 427 & $\begin{array}{l}\text { Lodhiyal and } \\
\text { Lodhiyal, 1997 }\end{array}$ \\
Maize & $66-111$ & $333-556$ & $86-161$ & Beale and Long, 1997 \\
\hline Wheat & $83-87$ & - & $117-133$ & Jorgensen, 2000 \\
\hline
\end{tabular}

Table 3. Cellulose, hemicellulose and lignin contents in common agricultural residues.

\begin{tabular}{lccc}
$\begin{array}{l}\text { Cignocellulosic } \\
\text { materials }\end{array}$ & Cellulose, \% & Hemicellulose, \% & Lignin, \% \\
Hardwoods stems & $40-55$ & $24-40$ & $18-25$ \\
Softwood stems & $45-50$ & $25-35$ & $25-35$ \\
\hline Corn cobs & 45 & 35 & 15 \\
Wheat straw & 30 & 50 & 15 \\
\hline Grasses & $25-40$ & $35-50$ & $10-30$ \\
Leaves & $15-20$ & $80-85$ & 0 \\
\hline
\end{tabular}

Source: Sun and Cheng, 2002.

were recorded for $\mathrm{N}$ and $\mathrm{P}$, while giant reed was characterised by significantly higher $\mathrm{K}$ concentration than miscanthus from July onwards.

Secondly, N, P and K nutrient contents generally reached their maximum values in summer. Supposing an autumnal harvest, we could expect nutrient contents of about $90 \mathrm{kgN} / \mathrm{ha}, 30 \mathrm{kgP} / \mathrm{ha}$ and $260 \mathrm{kgK} / \mathrm{ha}$ for giant reed and about $90 \mathrm{kgN} / \mathrm{ha}, 40 \mathrm{kgP} / \mathrm{ha}$ and $210 \mathrm{kgK} / \mathrm{ha}$ for miscanthus. Besides, supposing a winter harvest, nutrient contents could be reduced to $70 \mathrm{kgN} / \mathrm{ha}, 30 \mathrm{kgP} / \mathrm{ha}$ and $240 \mathrm{kgK} / \mathrm{h}$ a for giant reed and about $50 \mathrm{kgN} / \mathrm{ha}, 20 \mathrm{kgP} / \mathrm{ha}$ and $130 \mathrm{kgK} / \mathrm{ha}$ for miscanthus. In addition, although both crops show evident nutrient cycling, miscanthus appears to be able to recycle macronutrients to a higher extent than does giant reed. The miscanthus $\mathrm{C} 4$ pathway could explain its higher ability in reducing macronutrient uptakes compared to giant reed. Furthermore, both PRGs seem able to achieve higher dry matter production per unit of nutrient uptake (i.e. higher NUE) than arable crops.

Thirdly, from October to January, our results reported little variation of cellulose, hemicellulose and lignin percentage with no significant differences between the two species (38\% cellulose, $25 \%$ hemicellulose and $8 \%$ lignin). Therefore, in our environment, cellulose, hemicellulose and lignin contents appear not to be discriminative parameters in the 
choice of the harvest time.

In conclusion, our results highlighted that, under the environmental conditions of the Mediterranean area, a broad harvest period is possible (from autumn to winter). Nonetheless, the choice of harvest time cannot detract from environmental, economical and logistic considerations that can strongly affect the whole bioenergy chain sustainability.

\section{References}

Amougou N., Bertrand I., Machet J.M., Recous S., 2010. Quality and decomposition in soil of rhizome, root and senescent leaf from Miscanthus $\mathrm{x}$ giganteus, as affected by harvest date and $\mathrm{N}$ fertilization. Plant Soil DOI 10.1007/s11104-010-0443-x.

Angelini L.G., Ceccarini L., Bonari E., 2005. Biomass yield and energy balance of giant reed (Arundo donax L.) cropped in central Italy as related to different management practices. Eur. J. Agron. 22:375389.

Angelini L.G., Ceccarini L., Nassi o Di Nasso N., Bonari E., 2009. Comparison of Arundo donax L. and Miscanthus $\mathrm{x}$ giganteus in a long-term field experiment in Central Italy: analysis of productive characteristics and energy balance. Biomass Bioenerg. 33:635-643.

Beale C.V., Long S.P., 1997. Seasonal dynamics of nutrient accumulation and partitioning in the perennial C4-grasses Miscanthus $\mathrm{x}$ giganteus and Spartina cynosuroides. Biomass Bioener. 12:419428.

Cadoux S., Riche A.B., Yates N.E., Marchet J., 2011. Nutrient requirements of Miscanthus $\mathrm{x}$ giganteus: conclusions from a review of published studies. Biomass Bioener. D0I:10.1016/j.biombioe.2011.01.015.

Cherubini F., Jungmeier G., 2010. LCA of a biorefinery concept producing bioethanol, bioenergy, and chemicals from switchgrass. Int. J Life Cycle Ass. 15:53-66.

Christian D.G., Riche A.B., Yates N.E., 2008. Growth, yield and mineral content of Miscanthus $\mathrm{x}$ giganteus grown as a biofuel for 14 successive harvests. Ind. Crops Prod. 28:320-327.

Cosentino S.L., Patanè C., Sanzone E., Copani V., Foti S., 2007a. Effects of soil water content and nitrogen supply on the productivity of Miscanthus x giganteus Greef et Deu in a Mediterranean environment. Ind. Crops Prod. 25:75-88.

Cosentino S.L., Sanzone E., Bellomia L., Sortino 0., Belligno A., 2007b. Chemical composition and energetic value of perennial ligno-cellulosic species (Miscanthus x giganteus Greef and Deu. and Arundo donax L.) grown in Mediterranean region. Pages 820-824, Proc. 15th Eur. Biomass Conf. Exhib., Berlin, Germany.

Gomez K.A., Gomez A.A. (eds), 1984. Statistical procedures for agricultural research. John Wiley \& Sons Ed., New York, NY, USA.

Heaton E.A., Dohleman F.G., Long S.P., 2009. Seasonal dynamics of Miscanthus $\mathrm{x}$ giganteus and Panicum virgatum. GCB Bioener. 1:297-307.

Himken M., Lammel J., Neukirchen D., Czypionka-Krause U., Olfs H.W., 1997. Cultivation of Miscanthus under west European conditions: seasonal changes in dry matter production, nutrient uptake and remobilization. Plant Soil 189:117-126.

Jørgensen U., 2000. Wheat rye and triticale for energy - input, yield and quality. In: U. Jorgensen (ed). Do Energy Crops have a Future in Denmark? DJF rapport Markbrug 29:6-11.

Jørgensen U., Mortensen J., 1997. Perennial crops for fibre and energy use as a tool for fulfilling the Danish strategies on improving surface and ground water quality. In: S.E. Olesen (ed). Alternative Use of Agricultural Land. SP Report 18:12-21.

Jug A., Hofmann-Schielle C., Makeschin F., Rehfuess K.E., 1999. Shortrotation plantations of balsam poplar, aspen and willows on former arable land in the Federal Republic of Germany. II Nutritional status and bioelement export by harvested shoot axes. Forest Ecol. Manag. 121:67-83.

Kahle P., Beuch S., Boelcke B., Leinweber P., Shulten H.R., 2001. Cropping of Miscanthus in Central Europe: biomass production and influence on nutrients and soil organic matter. Eur. J. Agron. 15:171-184.

Keshwani D.R., Cheng J., 2009. Switchgrass for bioethanol and other value-added applications: A review. Bioresource Technol. 100:15151523.

Lemus R., Parrish D.J., Wolf D.D., 2009. Nutrient uptake by Alamo switchgrass used as an energy crop. Bioenerg. Res. 2:37-50.

Lodhiyal L.S., Lodhiyal N., 1997. Nutrient cycling and nutrient use efficiency in short rotation, high density central Himalayan Tarai poplar plantations. Ann. Bot. 79:517-527.

Long S.P., 1983. C4 photosynthesis at low temperatures. Plant Cell Environ. 6:345-363.

Monti A., Zatta A., 2009. Root distribution and soil moisture retrieval in perennial and annual energy crops in Northern Italy. Agric. Ecosyst. Environ. 132:252-259.

Nassi o Di Nasso N., Angelini L.G., Bonari E., 2009a. Improving energy crop cultivation in the Mediterranean region: nutrient content, uptake and nutrient use efficiency in giant reed (Arundo donax L.). Pages 321-322, Proc. 16th Nitrogen Workshop - Connecting Different Scales of Nitrogen Use in Agriculture, Turin, Italy.

Nassi o Di Nasso N., Angelini L.G., Bonari E., 2009b. Influenza dell'epoca di raccolta sulla resa e sulla composizione della biomassa di canna comune (Arundo donax L.) in Italia Centrale. Pages 141-142, Atti XXXVIII Convegno Nazionale della Società Italiana di Agronomia (SIA), Firenze, Italy.

Nassi o Di Nasso N., Angelini L.G., Bonari E., 2010. Influence of fertilisation and harvest time on fuel quality of giant reed (Arundo donax L.) in Central Italy. Eur. J. Agron. 32:219-227.

Neto C.P., Seca A., Nunes A.M., Coimbra M.A., Domingues F., Evtuguin D., Silvestre A., Cavaleiro J.A.S., 1997. Variations in chemical composition and structure of macromolecular components in different morphological regions and maturity stages of Arundo donax. Ind. Crops Prod. 6:51-58.

Öhgren K., Rudolf A., Galbe M., Zacchi G., 2006. Fuel ethanol production from steam-pretreated corn stover using SSF at higher dry matter content. Biomass Bioener. 30:863-869.

Rowe R.L., Street N.R., Taylor G., 2009. Identifying potential environmental impacts of large-scale deployment of dedicated bioenergy crops in the UK. Renew. Sust. Energ. Rev. 13:271-290.

Sassne P., Galbe M., Zacchi G., 2008. Techno-economic evaluation of bioethanol production from three different lignocellulosic materials. Biomass Bioener. 32:422-430.

Scordia D., Jeffries T.W., Copani V., Cosentino S.L., 2009. Production of second generation bioethanol from giant reed (Arundo donax L.). pp 1494-1498 in Proc. 17th Eur. Biomass Conf. and Exibition, Hamburg, Germany.

Sharma K.P., Kushwaha S.P.S., Gopal B., 1999. Nutrient dynamics in an Arundo donax wetland: nutrient uptake, seasonal changes in tissue concentration and release during in situ decomposition. Int. J. Ecol. Environ. Sci. 25:1-20.

Shatalov A.A., Pereira H., 2002. Influence of stem morphology on pulp and paper properties of Arundo donax L. reed. Ind. Crop Prod., 15:77-83

Smith R., Slater F.M., 2010. The effects of organic and inorganic fertilizer applications to Miscanthus $\mathrm{x}$ giganteus, Arundo donax and Phalaris arundinacea, when grown as energy crops in Wales, UK. Global Change Biol. Bioener. 2:169-179.

Smith R., Slater F.M., 2011. Mobilization of minerals and moisture loss during senescence of the energy crops Miscanthus $\mathrm{x}$ giganteus, 
Arundo donax and Phalaris arundinacea, in Wales, UK. Global Change Biol. Bioener. 3:148-157.

Sun Y., Cheng J., 2002. Hydrolysis of lignocellulosic materials for ethanol production: a review. Bioresource Technol. 83:1-11.

Van Soest P.J., Robertson J.B., Lewis B.A., 1991. Methods for dietary fiber, neutral detergent fiber, and nonstarch polysaccharides in relation to animal nutrition. J. Dairy Sci. 74:3583-3597.

Zub H.W., Brancourt-Hulmel M., 2010. Agronomic and physiological performances of different species of Miscanthus, a major energy crop. A review. Agron. Sustain. Dev. 30:201-214. 